\title{
Price Spread and Marketing Efficiency Measure Analysis of Tea Platation Crop in Mokokchung District, India
}

\author{
Imlibenla and Amod Sharma* \\ Department of Agricultural Economics, SASRD, Nagaland University, \\ Medziphema Campus, Nagaland, India \\ *Corresponding author
}

\section{Ke y w ords \\ Tea, price, Spread, Marketing, Efficiency, Analysis \\ Article Info \\ Accepted: \\ 10 May 2019 \\ Available Online: \\ 10 June 2019}

\section{A B S T R A C T}

A study was conducted to analyze the marketing cost, price spread, marketing channels, and marketing efficiency of different tea plantation farms in Mokokchung district of Nagaland state, both primary and secondary data were used. The primary data pertained to the year 2018-19 and was elicited from 90 tea plantation cultivators and 10 market intermediaries were also selected for the data collection through pre-tested questionnaires. The main findings reveals that 64 respondents ( 71.10 per cent) of the sample sold their produce through channel-I and the remaining 26 respondents ( 28.90 per cent) sold though channel-II $759183 \mathrm{~kg}$ (54.10 per cent) of plucked tea leaves were sold through channel-I and $644907 \mathrm{~kg}$ (45.90 per cent) were sold through Channel-II, respectively. The total marketing cost incurred in Channel-I was Rs 7.08/- per kg, the total cost incurred in channel-II was Rs 6.55/-, which showed that total marketing cost was more in Channel-I as compared to Channel-II. In both the channels, marketing margin obtained by the processing unit was Rs 52.14/- per $\mathrm{kg}$ of processed tea leaf. The marketing margin obtained by processing unit was high due to various value addition process carried out during processing. The total margin observed in Channel-I was Rs 77.94/-, which was slightly higher than Rs 76.94/- as obtained in Channel-II, respectively. The consumer's price for $1 \mathrm{~kg}$ of processed tea leaf is Rs 300.00. In case of channel-I, producer's share in consumer price was Rs 15.00/-, which was less than Rs 17.00/- as obtained in channel-II. The marketing efficiency in Channel-I was estimated to be 14.10 and in Channel-II it was 15.30, so it was found out that Channel-II was more efficient than Channel-I, respectively.

\section{Introduction}

India is the second largest producer of tea in the world after China. The country is home to a wide variety of teas including CTC tea, orthodox tea, green tea and organic tea. Unlike many other tea producing and exporting nations, India has a manufacturing base for both CTC and orthodox tea, in addition to green tea. India offers high quality specialty teas, such as Darjeeling, Assam Orthodox and high-range Nilgiri tea, which have a distinct aroma, strength, color and flavor. The tea industry in India is about 172 years old and it is perhaps one of the only industries which have maintained its leadership in terms of production over the past 150 years. Indian tea is among the finest 
in the world owing to strong geographical indications, heavy investments in tea processing units, continuous innovation, augmented product mix and strategic market expansion (Tea Board of India, 2018).

Nagaland is emerging as one of the nontraditional tea growing area with a large number of Naga people taking up tea cultivation as an alternate means of livelihood. This has made a significant impact on the pattern of agricultural land use, creation of rural employment opportunities, occupational structure shift and economic benefit to the people engaged in tea cultivation. However, the production of tea in Nagaland is very less as compared to other tea producing states despite its favorable agroclimatic, topographic and natural conditions for tea cultivation. The concept of small tea cultivation in Nagaland is relatively new compared to neighboring states like Assam and most of the tea growers lack technical knowledge of cultivation. The growers mostly rely on factory owners for dispersing their green leaves at a price fixed by the factory owners. In the aspect of marketing, many small tea farmers suffer from obtaining reasonable price for their produce which affects their profitability to a considerable extent (Sharma and Sharma, 2019).

Tea cultivation in Mokokchung district of Nagaland is being taken up by more farmers every year and factories have been established over the years. However, no study or research has been conducted till now by concerned department regarding marketing pattern aspects of tea in Mokokchung district of Nagaland. Taking all these into consideration the present research is designed in order to know the present scenario, and to address bottle-necks and provide suggestions in enhancing the tea industry in the state of Nagaland in coming days.

\section{Materials and Methods}

Mokokchung is a district of Nagaland state in India which is mainly occupied by the Ao Naga tribe. Its headquarters is Mokokchung town. This district covers an area of about $1615 \mathrm{sq} \mathrm{km}$ and is bounded by the state of Assam to its north, Wokha district to its west, Tuensang and Longleng district to its east, and Zunheboto district to its south. The selection of villages was done purposively based on the availability of tea growers. From Tuli sub-division, 6 villages were selected namely Anike, Wamaken, Merangkong, Kangtsung, Anakiyimsen and Wamakenyimsen. From each village, the list of farmers who were growing tea for the past 5 to 6 years obtained, from which 15 farmers were randomly selected so that there will be uniformity in their yield. Thus, altogether the total number of respondents were 90. The selected respondents were then categorized into three groups viz; marginal, small and large. Due to wide variation amongst the area under tea garden, the categorization was done by adding and subtracting the mean \pm standard deviation of the respondent's tea areas. The categorization was viz; Small: up to 0.70 ha, Medium: 0.71 to 3.20 ha and Large: 3.21 ha and above.

Marketing cost was calculated by estimating the cost incurred in the process of marketing of tea. The cost incurred after harvesting of the crop till it reaches the consumers generally constitutes the marketing cost. It includes transportation cost, handling cost, storage cost, market fees, weighing charges and labor charges for packing, loading and unloading. The marketing cost at various stages of marketing was calculated and finally the total marketing cost was computed (Choudhary et al., 2017).

Marketing margin at any stage of marketing was calculated as follows: 
$\mathrm{MM}_{\mathrm{i}}=\mathrm{SP}_{\mathrm{i}}-\left(\mathrm{PP}_{\mathrm{i}}+\mathrm{MC}_{\mathrm{i}}\right)$

Whereas: $\mathrm{MM}_{\mathrm{i}}=$ Marketing margin of the ith middleman.

$\mathrm{SP}_{\mathrm{i}}=$ Selling price of the ith middleman.

$\mathrm{PP}_{\mathrm{i}}=$ purchasing price of the ith middleman.

$\mathrm{MC}_{\mathrm{i}}=$ Marketing cost incurred by the ith middleman.

The price spread is the difference between the price paid by the consumer and the price received by the producer. It mainly consists of marketing costs and margins (Dinesh and Sharma, 2019; Jamir and Sharma, 2014). The price spread analysis was carried out by using the formula:

Producer's share in consumer's rupee $=\frac{\text { Producer's share }}{\text { Consumer's srice }} \times 100$

Marketing efficiency is the ratio of market output to the marketing input (Lal et al., 2003; Murry and Sharma, 2016). A detailed study of marketing efficiency on the produce of sampled respondents was determined. Shepherd's method was used to assess the efficiency of the marketing channels which is given by:

Marketing efficiency $=\frac{\text { Consumer's price }}{\text { Total marketing cost }}$

The process of estimating the marketing pattern and efficiency of tea leaves from producer till consumer is complicated as it involves processing in the middle of the channel, wherein, $3 \mathrm{~kg}$ of fresh tea leaves gets processed to only $1 \mathrm{~kg}$ of made tea. Despite the limitations, an attempt was made by the researcher to analyze the marketing pattern and efficiency of tea leaves, taking into account the information obtained from sampled respondents, 6 commission agents (1 from each village), 1 processing unit, 6 wholesalers and 6 retailers.

\section{Results and Discussion}

The marketing pattern of the sampled tea growers followed two channels. In Channel-I, the sampled farmers sold their produce to commission agents, who in turn sold the purchased tea to factory for processing. Here, the farmers do not incur any expense for marketing. However, the farmers were paid lesser by the commission agent as compared to factory purchase price. The difference in price was Rs 2 per $\mathrm{kg}$ of fresh plucked tea leaves. In Channel-II, the farmers sell their produce directly to tea factory at their own expense. Hence, they get better price for their produce as compared to those who sell to commission agents. Similar findings was obtained by Sharma and Singh (2001); Sakhrie and Sharma (2017).

Table 1 reveals that the marketing channels it was observed that 64.00 per cent of the sampled respondents sold their produce through channel-I and the remaining 28.90 per cent sold though channel-II. Those respondents who owned transportation facilities sold their produce themselves directly to processing unit, while the rest sold through channel-I, where commission agent was involved. Similar studies were carried out by Sharma and Tungoe (2011).

Table 2 reveals that the activity wise marketing cost incurred at various steps of marketing channel was estimated. The total cost incurred for marketing $1 \mathrm{~kg}$ of green leaf through Channel-I and Channel-II. The only difference between the two channels is the presence of commission agent in Channel-I, while all the sampled respondents produce were found out to be processed in the same factory. Therefore, marketing cost of processing unit remains same in both the channels. After the green leaf is processed in the processing unit, it is being marketed through wholesalers and retailers, therefore, 
from the point of processing unit the marketing costs remain same in both the channels. Certain quantity of processed tea leaf from the studied processing unit were also auctioned at Guwahati auction center, however, it has been neglected in the marketing channel by the researcher due to time limitation.

From the table 2 in channel-I, the total cost incurred by the commission agent was Rs 0.83 per $\mathrm{kg}$ of green leaf. Adding up all the cost for fuel, power, wages, factory overheads, general overheads, packing, tax and transportation, the total cost incurred by the processing unit for processing $1 \mathrm{~kg}$ of green leaf was Rs 4.19/-. The cost incurred by wholesaler and retailer for marketing $1 \mathrm{~kg}$ of processed tea leaf were Rs 0.86/- and Rs 1.20/-, respectively. While in Cha -nel-II, the cost incurred by the producer farmer was Rs 0.30/- per kg cost incurred by the processing unit, wholesaler and retailer were Rs 4.19/-, Rs 0.86/- and Rs 1.20/-, respectively. The total marketing cost incurred in Channel-1 was Rs 7.08/- per kg and the total cost incurred in channel-II was Rs 6.55/-, which shows that total marketing cost is more in Channel-I as compared to Channel-II, respectively. Similar studies were carried out by Sharma et al., (2010); Sharma (2013).

Table 3 reveals that the marketing margins of commission agents, processing unit, wholesalers and retailers had been calculated considering the value of $1 \mathrm{~kg}$ of green leaf till it reaches the consumers in processed form. Marketing margins for both the channels had been calculated separately. In channel 1, marketing margin for commission agent had been estimated as Rs 1 per $\mathrm{kg}$ of green leaf. After commission agent, the market intermediaries were same in both the channels. In both the channels, marketing margin obtained by the processing unit was
Rs 52.14/- per $\mathrm{kg}$ of processed tea leaf. The marketing margin obtained by processing unit was high due to various value addition process carried out during processing. Average marketing margin for the wholesalers were obtained as Rs 16.13/- per $\mathrm{kg}$ of processed tea leaf which was higher than the marketing margin obtained by the retailers (Rs 8.67/- per $\mathrm{kg}$ ). So, the total margin observed in Channel-I was Rs 77.94/-, which was slightly higher than Rs 76.94/- as obtained in Channel-II, respectively. Similar studies were in the line with Yadav et al., (2018).

The price spread analysis of the present study refers to the difference between price paid by the consumer and the net price received by the farmer for an equivalent quantity of tea leaf. The consumer's price for $1 \mathrm{~kg}$ of processed tea leaf is Rs 300.00/- which is made from $3 \mathrm{~kg}$ of green leaf. So in order to estimate the producer's share of $1 \mathrm{~kg}$ of green leaf in consumer's price, the price of processed tea has been divided by 3 . The producers share in consumer price was found out to be very less which is because of value addition done in the processing unit. In case of channel-I, producer's share in consumer price was Rs 15.00/-, which is less than Rs $17.00 /-$ as obtained in channel-II, respectively. Similar studies were carried out by Tangjang and Sharma (2018).

Table 4 reveals that the marketing efficiency is the ratio of market output to the marketing input. A detailed study of marketing efficiency on the produce of sampled respondents had been determined in this segment. Here, the researcher had used Shepherd's method to assess the efficiency of the two channels. The marketing efficiency in Channel-I was estimated to be 14.10 and in Channel-II it was 15.30. Hence, it can be concluded that Channel-II is more efficient than Channel-I. This shows that as 
intermediaries increases between producer decreases. Similar studies were carried out by and consumer, marketing efficiency Sharma et al., (2018) (Fig. 1-3).

Table.1 Marketing channels of tea

\begin{tabular}{|c|c|c|c|c|}
\hline S. N. & Particulars & Channels & $\begin{array}{c}\text { Growers } \\
\text { involved (nos) }\end{array}$ & $\begin{array}{l}\text { Quantity } \\
\text { sold (kg) }\end{array}$ \\
\hline 1. & Channel-I & $\begin{array}{l}\text { Producer-Commission agent-Processing } \\
\text { unit-Wholesaler-Retailer-Consumer }\end{array}$ & $\begin{array}{c}64 \\
(71.10)\end{array}$ & $\begin{array}{l}7,59,183 \\
(54.10)\end{array}$ \\
\hline 2. & Channel-II & $\begin{array}{l}\text { Producer-Processing unit-Wholesaler- } \\
\text { Retailer-consumer }\end{array}$ & $\begin{array}{c}26 \\
(28.90)\end{array}$ & $\begin{array}{c}6,44,907 \\
(45.90)\end{array}$ \\
\hline \multicolumn{3}{|r|}{ Total } & $\begin{array}{c}90 \\
(100.00)\end{array}$ & $\begin{array}{c}14,04,090 \\
(100.00)\end{array}$ \\
\hline
\end{tabular}

(Parenthesis indicate percentage to the total)

Table.2 Marketing cost incurred in different channels for $1 \mathrm{~kg}$ of tea leaf (Rs)

\begin{tabular}{|c|c|c|c|}
\hline S. N. & Particulars & Channel-I & Channel-II \\
\hline 1. & \multicolumn{3}{|c|}{ Cost incurred by producer } \\
\hline 2. & Transportation cost & 0.0 & 0.20 \\
\hline 3. & Sub total & 0.0 & 0.20 \\
\hline 4. & \multicolumn{3}{|c|}{ Cost incurred by commission agent } \\
\hline 5. & a. Transportation cost & 0.50 & 0.0 \\
\hline 6. & b. Labour charge for loading and unloading & 0.50 & 0.0 \\
\hline 7. & Sub total & 1.00 & 0.0 \\
\hline 8. & \multicolumn{3}{|c|}{ Cost incurred by processing unit } \\
\hline 9. & a. Fuel(firewood) & 0.82 & 0.82 \\
\hline 10. & b. Power (electricity) & 1.05 & 1.05 \\
\hline 11. & c. wages & 0.50 & 0.50 \\
\hline 12. & d. Factory overheads & 0.78 & 0.78 \\
\hline 13. & e. General overheads & 0.44 & 0.44 \\
\hline 14. & f. Packing & 0.26 & 0.26 \\
\hline 15. & g. Tax & 0.17 & 0.17 \\
\hline 16. & h. Transportation & 0.17 & 0.17 \\
\hline 17. & Sub total & 4.19 & 4.19 \\
\hline 18. & \multicolumn{3}{|c|}{ Cost incurred by wholesaler } \\
\hline 19. & Transportation cost & 0.86 & 0.86 \\
\hline 20. & Sub total & 0.86 & 0.86 \\
\hline 21. & \multicolumn{3}{|c|}{ Cost incurred by retailer } \\
\hline 22. & Transportation cost & 1.20 & 1.20 \\
\hline 23. & Sub total & 1.20 & 1.20 \\
\hline 24. & Total marketing cost & 7.25 & 6.45 \\
\hline
\end{tabular}


Table.3 Marketing margins involved in tea marketing (Rs)

\begin{tabular}{|c|c|c|c|}
\hline S.N. & Particulars & Channel-I & Channel-II \\
\hline 1. & Price received by the farmer & 15 & 17 \\
\hline 2. & Commission agent's purchase price & 15 & - \\
\hline 3. & Cost incurred & 1.00 & - \\
\hline 4. & Commission agent's selling price & 17 & - \\
\hline 5. & Margin & 1.00 & - \\
\hline 6. & Processing unit's purchase price & 17 & 17 \\
\hline 7. & Cost incurred & 4.19 & 4.19 \\
\hline 8. & Processing unit's selling price & 73.33 & 73.33 \\
\hline 9. & Margin & 52.14 & 52.14 \\
\hline 10. & Wholesaler's purchase price & 73.33 & 73.33 \\
\hline 11. & Cost incurred & 0.86 & 0.86 \\
\hline 12. & Wholesaler's selling price & 90.33 & 90.33 \\
\hline 13. & Margin & 16.13 & 16.13 \\
\hline 14. & Retailers purchase & 90.33 & 90.33 \\
\hline 15. & Cost incurred & 1.2 & 1.2 \\
\hline 16. & Retailer's selling price & 100 & 100 \\
\hline 17. & Margin & 8.67 & 8.67 \\
\hline 18. & Total Margin & 77.94 & 76.94 \\
\hline
\end{tabular}

Table.4 Price spread and marketing efficiency analysis (Rs/kg)

\begin{tabular}{|c|l|c|c|}
\hline S. N. & \multicolumn{1}{|c|}{ Particulars } & Channel-I & Channel-II \\
\hline $\mathbf{1 .}$ & Producer's price & 15 & 17 \\
\hline $\mathbf{2 .}$ & Total marketing cost & 7.25 & 6.45 \\
\hline $\mathbf{3 .}$ & Total marketing margin & 77.94 & 76.94 \\
\hline $\mathbf{4 .}$ & Consumer's price & 100 & 100 \\
\hline $\mathbf{5 .}$ & Producer's share in consumer price (\%) & 15.00 & 17.00 \\
\hline $\mathbf{6 .}$ & Value added by the marketing system & 85 & 83 \\
\hline $\mathbf{7 .}$ & Marketing Efficiency (by Shepherd's method) & 14.11 & 15.27 \\
\hline
\end{tabular}

Fig.1 Percentage usage of different channels by growers

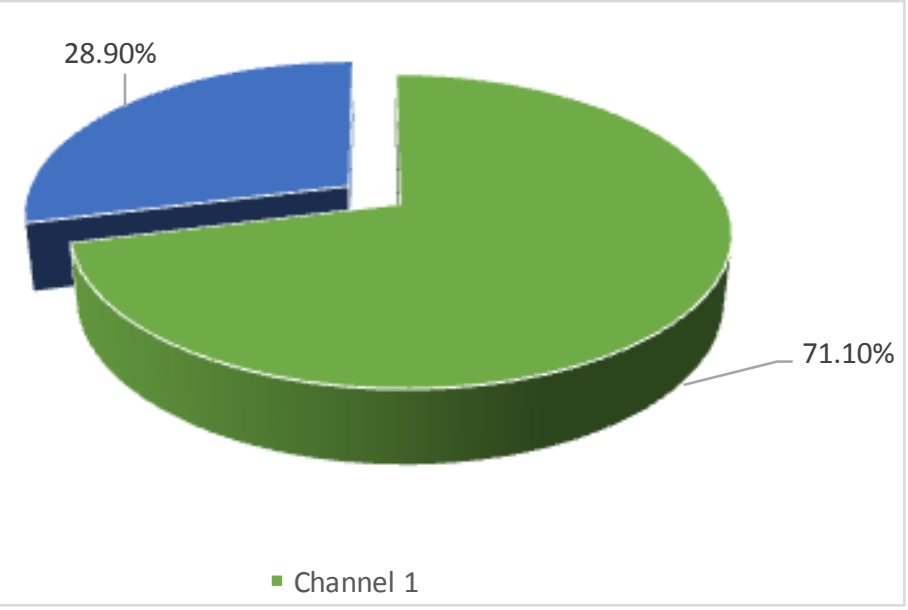


Fig.2 Quantity sold through different channels

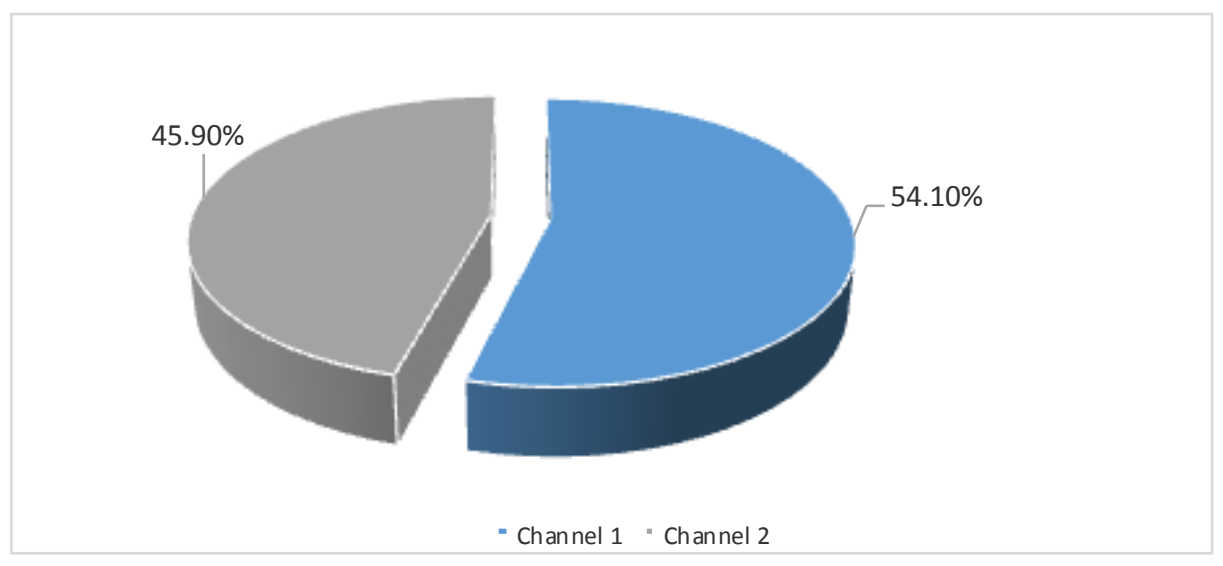

Fig.3 Price spread and marketing efficiency

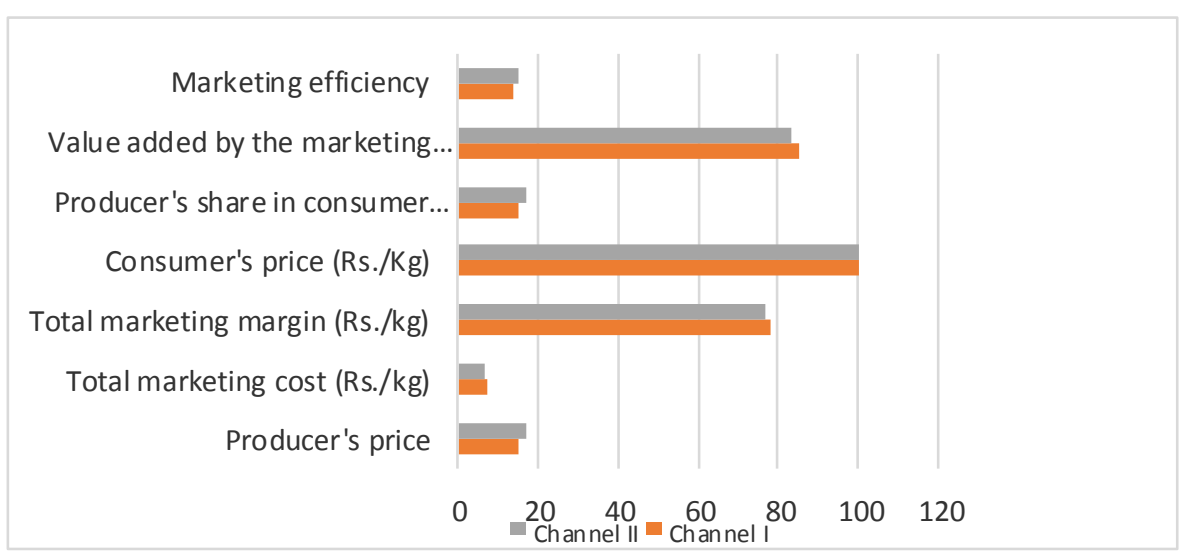

Based the present study some of the conclusions must be drawn for future guidelines viz., the marketing pattern of the sampled tea growers followed two channels. In Channel-I, sold their produce to commission agents, who in turn sold the purchased tea to processing unit for processing. In Channel-II, the farmers sell their produce directly to tea factory at their own expense. Hence, they get better price for their produce as compared to those who sell through commission agents. The total marketing cost incurred in Channel-I was Rs 7.08/- per $\mathrm{kg}$ and the total cost incurred in channel-II was Rs 6.55/-, which showed that total marketing cost was more in Channel-I as compared to Channel-II. The total margin observed in Chanel-I was Rs 77.94/-, which was slightly higher than Rs 76.94/- as obtained in Channel-II. The marketing efficiency in Channel-I was estimated to be 14.1 and in Channel-II it was 15.3.

\section{References}

Choudhary, Ramjilal.; Rathore, D.S. and Sharma, Amod. 2017. An Economics Analysis of Production and Marketing of Groundnut in Porbandar District of Gujarat. Economic Affairs. 62(3). September: 547-553.

Dinesh, V. and Sharma, Amod. 2019. Marketing Margin, Price spread and Marketing Efficiency analysis of 
different Poultry Farms. International Journal of Current Microbiology and Applied Sciences. 8(6). (Paper Accepted for publication).

Jamir, Moanukshi. and Sharma, Amod. 2014. A Sustainable Production and Marketing of cucumber crop in the Hilly Zone of Nagaland. Technofame. 3(1). May: 61-66.

Lal, R. C. Singh, J. Sharma, A. and Tyagi, D. B. 2003. Marketable surplus and marketing Behaviour of the farmers - A Case Study of Wheat Growers in Agra District of Uttar Pradesh. Indian Journal of Agricultural Marketing. 17(2). May to August: 106-110.

Murry, N. and Sharma, Amod. 2016. Production and Marketing of Banana Cultivation in Wokha district of Nagaland. Nagaland University Research Journal. 9. December: 49-65.

Sakhrie, Ruselono. and Sharma, Amod. 2017. Price Spread and Marketing Efficiency in Marketing of Bamboo Shoots in Dimapur District of Nagaland. The Journal of Rural and Agricultural Research. 17 (1). January: 15-19.

Sharma, A. and Singh, A. K. 2001. Price Spread of Potato Farmers by Different Farm Size Group in Firozabad District of UP. Andhra Agricultural Journal. 48 (1 and 2). January to June: 124-127.

Sharma, A. Singh, J. Ahmad, B. Tyagi, D. B. and Singh, N. P. 2010. Production and Marketing of Walnut in Budgam District of Jammu and Kashmir. Indian Journal of Agricultural Marketing. 24 (1). January-April: 75-85.

Sharma, Amod. 2013. Economics of
Production and Marketing of King Chilli in Dimapur District of Nagaland. Indian Journal of Agricultural Marketing. 27(2). May-August: 128141.

Sharma, Amod. and Tungoe, B. L. Mahalo. 2011. Price Spread and Marketing Efficiency in Marketing of Potato in Wokha District of Nagaland. Progressive Agriculture. 11(1). February: 26-27.

Sharma, Amod.; Kichu, Yimkumba. and Sharma, Pradeep. Kumar. 2018. Sustainable economic analysis and constraints faced by the pineapple growers in Nagaland. Progressive Agriculture. 18(1). February: 27-33.

Sharma, Archana. and Sharma, Amod. 2019. Marketing Pattern and Marketing Efficiency of Organic Large Cardamon and Ginger Spices Grown in East District of Sikkim. International Journal of Current Microbiology and Applied Sciences. 8(5): 1359-1368.

Tangjang, Avicha. and Sharma, Amod. 2018. Marketing Pattern of Large Cardamom (Amomum Sabulatum) in Tirap district of Arunachal Pradesh. International Journal of Current Microbiology and Applied Sciences. 7(5). May: 25992606.

Yadav, Mukesh. Kumar.; Sharma, Amod.; Kumar, Ajay. and Nakhro, Rokoneituo. 2018. Study on Marketing Efficiency of Rapeseed \& Mustard crop in Jaipur district of Rajasthan. International Journal of Economic Plants. 5(2). May: 80-85. www.teaaboardofindia.org.in. Accessed on $03^{\text {rd }}$ May 2018.

\section{How to cite this article:}

Imlibenla and Amod Sharma. 2019. Price Spread and Marketing Efficiency Measure Analysis of Tea Platation Crop in Mokokchung District. Int.J.Curr.Microbiol.App.Sci. 8(06): 1164-1171. doi: https://doi.org/10.20546/ijcmas.2019.806.144 